\title{
Drug Addicts: Psychosocial Factor Contributing to Relapse
}

\author{
Alia Ashrani Azmi ${ }^{1,}$, Hussin H. $^{1}$, Siti Intan Diyana Ishak. ${ }^{1}$ and Nur Suriaty Daud@Fhiri ${ }^{1}$ \\ ${ }^{1}$ School of Human Development and Technocomunication, Universiti Malaysia Perlis, Perlis, Malaysia
}

\begin{abstract}
This article present about relapse among drug addicts in rehabilitation center. In Malaysia, many drug addicts relapse to drug use after discharged from successful treatment at rehabilitation center. Various effort and the authorities involved in assisting the National Anti-Drug Agency (NADA) efforts to cure and treat drug addicts. This article aims to examine the factors that affect relapse among drug addicts. Therefore, this article will discuss aspects of psychosocial factors including self-efficacy, family support, friends support and community support. Psychosocial factors, such as aspects of self-efficacy, family support, friends support and community support, had significant relationships with relapse. Psychological factors are also vital to design adequate treatment strategies. Thus, this article evaluating psychosocial factor as main factors that influenced the relapse addictions tendency amongst addicts.
\end{abstract}

\section{Introduction}

The problem of drug addiction is not a new issue in our country, Malaysia and the world. The problem of drug addiction is a problem that is difficult to recover. Addiction is a chronic disease that will recur in the absence of drug addicts in the body causing pain due to drug withdrawal syndrome. This situation is a cause of drug addicts taking drugs back pain due to drug withdrawal syndrome can be stopped [1].

The drug problem is a global problem. Activities production of various types of drugs is constantly increasing. This is supported by high demand. An international political change with the end of the cold war between the great powers of the world, have a negative impact in the fight against drugs. This is because the world is now considered no longer boundaries and everyone is free and out of a country without restrictions. Communication and transportation systems are increasingly sophisticated help facilitate their movement. For those involved with with drug activity, the development of this kind of operation was expected because they become more smooth and widespread.

Based on the statistics available from the National Anti-Drugs Agency (NADA), from January to June 2010 , some 3,095 of 12,079 drug addicts were detected as repeat offenders or relapse.

The number of repeat offenders was found to be increased compared to only 1,136 people repeat offenders were detected from January to June 2009 (NADA 2010). Meanwhile, a total of 2,792 new cases and 1,968 cases of drug addicts has been detected repeatedly during the January to June 2012, in which case repeatedly fell by $24.20 \%$. This situation is alarming because the problem of relapse in Penang and Kuala Lumpur are still exceed his increase.

\subsection{Objective of the paper}

Objectives of this paper are to find out psychosocial factors of relapse as follows:
a. Self-efficacy
b. Friends support
c. Family Support
d. Community Support

Result are taken from the research papers which have been done their research on the psychological factors of relapse. 


\section{Methodology}

The study is based on previous research method to review psychosocial factor contributing to relapse. The secondary data is drawn from books, journals and various reports published by agencies working in this fields. There are only few researches conducted studies to analyze factors contributing to relapse. Result are taken from the research papers which have been done their research.

\section{Result and Discussion}

According to Mahmood [2] generally means addicts relapse drug reuse of the original drug or other type after treatment and rehabilitation programs. From the above definitions can be formulated that relapse is the failure of addicts who have been through the process recovery to continue free from drugs. According to Childress [3], relapse is a return to the use the drug after a period free from dependence on the material while they continue constantly trying to recover.

Relapse is a difficult problem and challenge in the process of maintaining the recovery in addicts. Whereas according to Rasmussen [4], relapse defines as the reuse of relapse after stopping taking the drug for a certain period. Dennis [5] measures the definition of relapse of the behavior of the process of returning to a state of unhealthy behaviors that lead to the re-use of drugs and experiencing signs of change in terms of attitudes, thoughts and ways of behaving.

According Fig. 1, [6] Marlatt and Gordon reported that billing factor for relapse started as High Risk Situations. High-risk situations is the state that has a high influence to bring back a former addict takes drugs. High-risk situations for relapse is composed of three situations, namely (i) the negative emotion, (ii) experiencing interpersonal conflict and (iii) to face the social pressure of the surrounding circumstances.

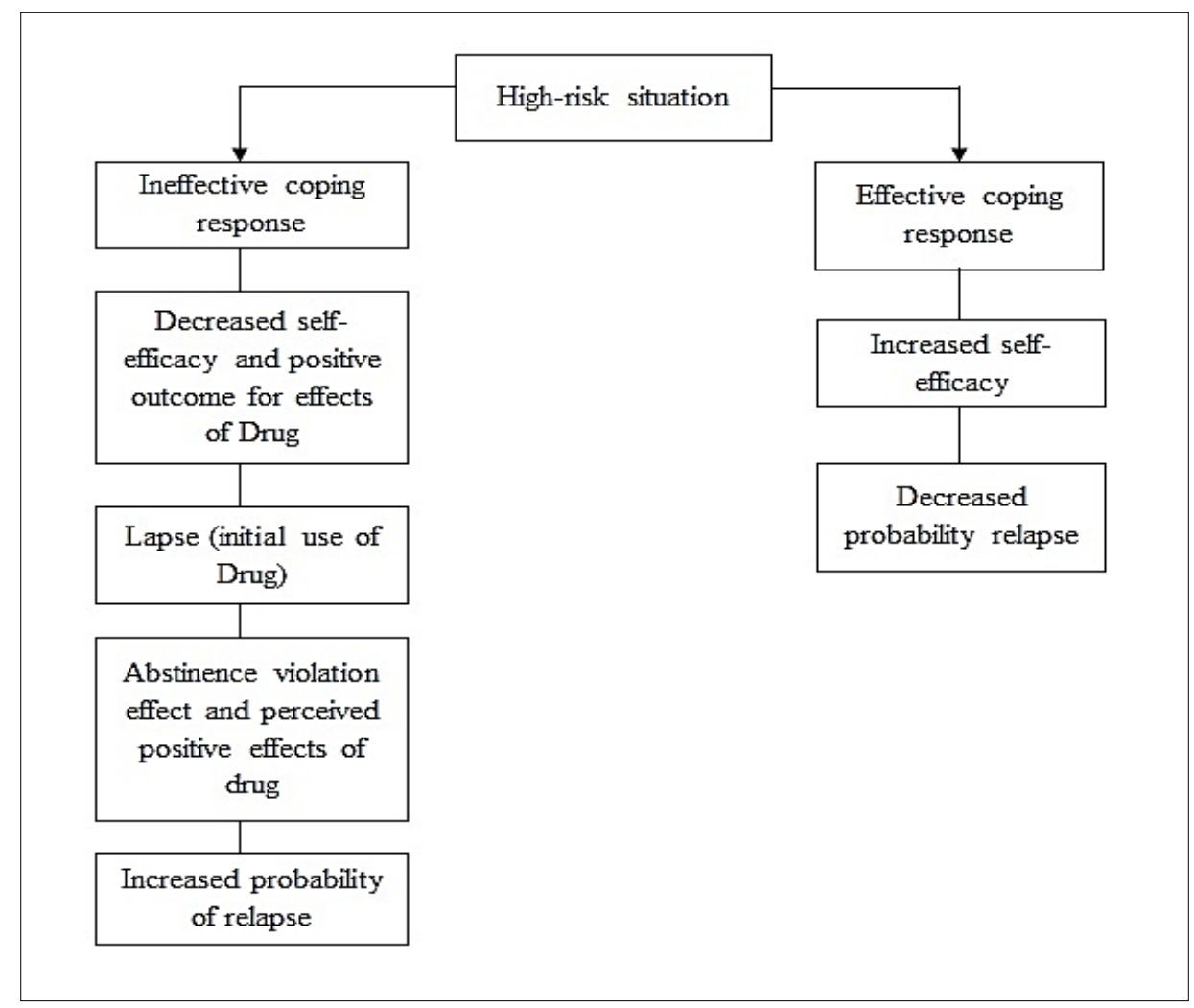

Fig. 1. Cognitive behavior model [6] 


\subsection{Self-efficiency}

Other relapsed promoting factor is self-efficacy, defined as a degree to which an individual feels confident and capable performing a certain behavior in a specific situational context. According to Nurhazlina and Azlinda [7], the study said two from eight respondents fall back using drugs after completion of treatment because they do not have strength and confidence in themselves that they were living without drugs or more clearly faced with self-esteem problem. Reported by Fauziah Ibrahim [8] said most addicts have a low self-esteem to overcome the problems that lie ahead, it is easy to give up and not be able to resolve a problem with a positive and intelligent. Due to these things, so they are easily influenced by things that lead to the occurrence of the issue of relapse. Cheung et al [9], identified that nine people from 21 drug users surveyed managed to refrain from using the drug because it has high self-confidence as a result of satisfaction in their lives who have a job and a steady income.

Recent studies have found the features of relapse for those who have feelings of depression, negative thoughts and think of all the things difficult to resolve, thinking immature, unable to manage feelings and emotions well, often confused, depressed and irritable. In this study, a total of $79.8 \%$ of respondents admitted that they often produce feelings of anger by screaming and yelling and some $60 \%$ of the respondents admitted often complain about unnecessary things. This situation is giving rise to confusion, disorder and emotional instability among addicts relapse and thus causing them classified as high-risk individuals relapse [4]. Whereas according to Mahmood [10], found that drug addicts are receiving treatment and rehabilitation of drug rehabilitation centers have a poor psychological state. They have a level of self-efficacy moderately low, still use this type of mechanism martial primitive and immature and has a personality that is not normal, such as high levels of anxiety, paranoia, emotional instability, tension and depression are high.

Previous research has shown that characterizes individuals who relapse have a level of depression, stress and anxiety disorders uncontrolled besides no acceptance or family support to free themselves from continuing to use the drug again. For example, some $72 \%$ of respondents in the study admitted that they often felt depressed, sad, moody and weepy. This decision gives the impression that an addict relapses have character and personality are less mature and rely on others to get support for maintaining a drug-free lifestyle [5] Dennis. Previous research has established that the study of the question of relapse to 327 subjects were divided into five groups of drunken behavior, smoking, heroin addicts, gamblers and nutrition that cannot be controlled Cummings [11]. Subjects who used to deal with the problem of relapse and the average age ranged from 30 to 45 years. The study found that as $(30 \%)$ drug addicts involved in the issue of relapse it is because low self-efficacy.

\subsection{Friends Support}

Amongst other factors that have been associated with relapsed addiction are peer pressures especially from the old friends who still use drugs. Studies on serious drug users found that factors that led to a total of 17 respondents who are drug users and alcohol users who had participated in rehabilitation programs in Queensland, Australia fall back to drug because peer influence Hammer-Bacher [12]. Saodah Siraj [13] in his research found that peer influence has to do with behavior problems. The findings showed that the respondents admitted often invited friends to hang out at the mall and also agreed that the partners better understand their problems compared to their own family members. The findings showed that $50 \%$ of respondents agreed that they easily accept a friend invitation them to try drugs.

Kaplan [14], contended that total of $30.6 \%$ of respondents agreed that their stand is wobbly when urged by a friend to try the drug. The results showed that most individuals with drug problems is because they are influenced by a reference group which is a social network used by individuals as a reference to his daily behavior. In this case, the reference group can be associated with a group of peers. In adolescence, students spend more time with peers such as within school hours. Pressure from peer group eventually lead students to drug abuse. Insistence that they received led to the establishment of an increasingly shaky to be involved in drug abuse.

Other previous report by Pruitt et al [15] found that among 1,004 adolescents grades 8 and 10 in a small community in Central and Eastern Texas, which again involved the use of materials as having at least involved with the consumption of alcoholic beverages once a week and also have a friend who is involved with the drug marijuana, smell, and other amphetamines. Nik Mohd Zaini found that this research is a field study conducted at the Rehabilitation Centre Besut, Terengganu. The subjects are 190 trainees who have different demographic factor and is undergoing treatment and rehabilitation. The results show the influence of peers is an important factor causing drugs by addicts. Life that cannot be controlled is a major cause of drug treatment participation. The study also found the drug to be influenced by their friends because there is a sense of 
belonging within the group itself. In addition, some of the conditions specified by members of the group also made them stuck with drugs. Peers have a strong influence on a friend-pawn, especially at the junior level.

Manja Mohd Ludin [16] in his research found that kids in high school are usually form groups according to their respective interests. The extent of the interest of the individual is dependent on the extent to which the strength of attraction peers. When a person begins to engage with peers who use drugs there will be attractions for them also engage in drug abuse. Students will begin to be affected when they often invite their friends to use drugs. A total of $41.7 \%$ of respondents agree that they are easy to follow treatment friend that led to drug abuse, such as smoking.

Tec [17] Studies on the influence of the peer group over the behavior of marijuana use. The results of these studies show the use of marijuana as social activities which often occurs in the peer group. This shows that students easily lead to treatment of peers. The study also states that teens who use marijuana are more closely by peer group than the family. The results showed $41.7 \%$ of respondents agreed that they do not care if their friends are involved in drug abuse. Apathy or indifference can lead to influence the students to experiment with drugs when many of their peers are involved in drug abuse.

\subsection{Family Support}

Family support also identified contributing to the relapsed addiction tendency. According to Noor Zalifah, in his case study on cases under the supervision of the National Anti-Drug Agency (NADA), which examines the causes of addiction relapse said the families are factors that most influence them toward drug addiction relapse. Pressure from families who want addicts to recover and turn immediately made them forget the charge for the immediate pressure. In addition, a high desire to drugs to make them re trapped in addiction. Amongst other factors that have been associated with relapse addiction is family.

Mattoo, Chakrabarti and Anjaiah [18] in their study of 30 male addicts to see psychosocial factors associated with relapse. The study looked at the relationship between demographics, medical and psychosocial factors with relapse. The results showed that family history of drug addiction and family have a high rate of relapse that most affect their return to the billing. Fauziah Ibrahim [19] found that a total of $96.3 \%$ of drug addicts who engage in the issue of relapse said they received a moderate level of family support to a high level. Of these, 15 (3.8\%) of respondents stated that they received a low level of family support. While $300(75.0 \%)$ received the support of a simple family of $85(21.3 \%)$ received a high level of support.

Research by Ibrahim, a total of $36.1 \%$ of respondents agreed that their parents often quarrel caused them to get involved in drug abuse. This suggests that the failure of parents to set a good example to the children. Not a good value will result in depressed teens and began to engage in negative things like drugs. Parents certainly have an important role and responsibility in maintaining discipline children. Parents need to demonstrate the value of the moral high enough to guide their children. In addition, children who start moving into adolescence will find peace outside if there was a tense at home. According to a random survey conducted on 60 family units in the north of the peninsula, found $95 \%$ of respondents from among the civil society the view that they assume addicts as a group of people who are not useful to the country. Only $18 \%$ among them thought that the drug is a disease that must be cured. While $6.0 \%$ felt that all addicts should be brought to a place far away from society and not allowed back because of mistakes made [20].

\subsection{Community Support}

Community support is the effects of psychological factors that contributes towards relapsed addiction tendency amongst addicts. Dittmar, Ratnasinggam [21], Study in Malaysia about the influence of people on drug addicts who look from the point of view of drug addicts and point of view of society in terms of moral and ethical found addicts has shown a positive attitude but the situation is at odds with a society where drug addicts are often considered resist and ignore values community. The negative attitude of the society towards recidivist addicts cause they feel alienated and will repeat the habit relapse drugs for solace and settle the conflict themselves. What is the truth faced by respondents to this study.

Research by Chen [22] related to social support, spiritual and addiction recovery program explained that social support from the local community through meetings of former drug users in association involving integration into society and spirituality programs are important to reduce the negative consequences of the formation pressure encountered during the recovery process. This clearly has pointed out that society should provide support in the form of social and physical as it gives them unconditionally and providing jobs if necessary to drug users so that they have the confidence to continue to change and finally off drugs. 
Fauziah Ibrahim and Naresh Kumar [23] study the factors that influence relapse in Malaysia. The study was conducted on 400 people who are repeat offenders in select from eight rehabilitation centers in Peninsular Malaysia. They studied seven variables were considered as the main influence on the relapse of self-esteem, family support, peer support, community support, employer support and the effectiveness of rehabilitation programs. The researchers found that the confidence and support of the most influential collectors of charge. Many drug addicts have self-esteem and low and they do have the power within themselves. $64 \%$ also said the society does not accept them back into society and society has always looked askew to those like them. In addition, people also often suspect them when there is an incident such as theft and they continue on the label as a performer.

Mohammad Roslan [24] study states to ensure that no cases of recurrent drug addicts, every member of society must change the perception of former drug addicts. There are a few cases where public support to former drug addicts were able to make this former drug addicts be useful to the society and the state. A former drug addicts involved in drug abuse for fourteen years to recognize the support of family and community acceptance helped her to turn and stop drug abuse. Even former drug addicts just need attention and support from the community, but the attention and support plays a very big role in encouraging a person to go through the recovery process. The criticism of society and less drug resistance makes the bill because there is no place to complain and would not tolerate insults and denigration of the family and the local community.

\section{Conclusion}

Relapse among drug users in rehabilitation centers occur due to the influence of psychosocial factors. Therefore, as an individual who is directly involved in the helping profession and service delivery in any rehabilitation center in Malaysia should look for these recurring billing problems as a whole, rather than only on the shoulders of drug users involved. A comprehensive commitment to the task and this trust needs to be applied to all levels of personnel to the philosophy of recovery and rehabilitation policy is understood and can be implemented honestly and effectively. There can produce individuals who are advanced, productive and virtuous. The involvement of family, community and voluntary organizations was needed to educate and prevent crime. A safe social environment, free from abuse is certainly the hope of the people and the country.

\section{Reference}

1. H. Habil, M. Ali Mohd, Penyalahgunaan Dadah Hidup Tidak Beerti Maut Menanti (Dewan Bahasa dan Pustaka: Kuala Lumpur, 1999)

2. N. M. Mahmood, (2006). Peranan Institusi Keluarga dalam pencegahan gejala sosial dan penagihan dadah. In Azlin Hilma, H., Fatimah Zaily, A.R., Rusimah, S., dan Yusmarhaini (Ed.), Isu-isu dan Pendidikan Kerja Sosial (Sintok, UUM, 2006)

3. A. R. Childress, Understanding Addiction. From http://www.hbo.com/addiction/understandin g

4. S. Rasmussen, Addiction Treatment: Theory and Practice (Carlifornia. Sage Publication, 2000)

5. C. D. Dennis, C.D. (1989). Relapse Prevention: Treatment Alternatives and Counseling Aids. Tab Books Inc, Blue Ridge Summit, PA.

6. G. A. Marlatt, J. R. Gardon, Relapse Prevention: Maintenance Strategies in the treatment of Addictive Behaviors (New York: Guilford Press, 1985)

7. M. A. Nurhazlina, A. Azlinda, Malaysian Journal of Social Policy and Society 6, (2009)

8. Fauziah Ibrahim, Bahamah Abu Samah, Mansor Talib, Mohamad Shatar Sabran, Jurnal Antidadah Malaysia Jilid 5 (2009)

9. C. K. Cheung, T. Y. Lee, C. M. Lee, Factors in successful relapse prevention among Hong Kong drug addicts. Treating Substance Abusers in Correctional Context: New Understanding, New Modalities (2003) From http://www.HaworthPress.com

10. N. M. Mahmood, Perubahan Psikologikal dari segi harga diri, profil personality dan penggunaan mekanisme bela diri di kalangan penagih yang mengikuti pemulihan serenti, (Universiti Kebangsaan Malaysia, Bangi, 1995)

11. C. Cumming, J. R. Gordon, G. A. Marlatt, Relapse: Prevention and Prediction. The Addictive Behaviours: Drug Abuse, Smoking and Obesity (Britain: Pergamon Press, 1980) 
12. M. Hammer-Bacher, M. Lyvers, Journal Substance Use 11 (6), 387-394 (2006)

13. Saodah Siraj, Faktor-faktor yang mendorong kepada berlakunya masalah tingkah laku pelajar-pelajar di Sekolah Menengah Kulai (UTM, Johor, 2000)

14. D. B. Kaplan, Journal of Drugs Issues 26 (1996)

15. B. E. Pruitt, P. M. Kingery, E. Mirzaee, G. Heuberger, R. Hurley, Journal of Drug Education 21 (1), 36-56 (1991)

16. Manja Mohd Ludin, Psikologi Sosiologi Dan Falsafah Dalam Pendidikan (Kuala Lumpur: Dewan Bahasa Dan Pustaka, 1990)

17. N. Tec, Journal of the Marriage and the Family 32, 48-58 (1970)

18. S. K. Matttoo, S. Chakrabarti, M. Anjaiah, Psychosocial Factors Associated with Relapse in Men with Alcohol or Opiate Dependence (India: Chandigarh, 2009)

19. Fauziah Ibrahim, Bahaman Abu Samah, Mansor Abu Talib, Mohamad Satar Sabran, Faktor menyumbang kepada penagihan relaps dalam kalangan penagih dadah PUSPEN di Semenanjung Malaysia (Bangi: Universiti Kebangsaan Malaysia, 2008)

20. N. M. Mahmood, Jurnal PERKAMA 6 (1996)

21. M. Dittmar, M. Ratnasingam, V. Navaratnam, A Comparative Analysis of the Psychological Profile of Institusionalised Drug Using Population Minden (USM: Pusat Penyelidikan Dadah Kebangsaan, 1984)

22. G. Chen, International Journal of Offender Therapy and Comparative Criminology 50(3), (2006)

23. Fauziah Ibrahim \& Naresh Kumar, Asian Social Science Journal 5(12) (2009)

24. Mohamad Roslan Saad, Sikap Masyarakat Terhadap Penagih Dadah (Sabah: Universiti Malaysia Sabah, 2010) 